\title{
EUROPEAN ENVIRONMENTAL POLICY AND PUBLIC PROCUREMENT - CONNECTED OR DISCONNECTED?
}

\author{
Ondrej Blažo \\ Comenius University in Bratislava, Faculty of Law ${ }^{1}$ \\ ondrej.blazo@flaw.uniba.sk \\ Hana Kováčiková \\ Comenius University in Bratislava, Faculty of Law ${ }^{2}$ \\ hana.kovacikova@flaw.uniba.sk \\ Lucia Mokrá \\ Comenius University in Bratislava, Faculty of Social \\ and Economic Sciences, Faculty of Law ${ }^{3}$ \\ lucia.mokra@fses.uniba.sk
}

BLAŽO, Ondrej; KOVÁČIKOVÁ, Hana; MOKRÁ, Lucia. European Environmental policy and public procurement - connected or disconnected? International and Comparative Law Review, 2019, vol. 19, no. 2, pp. 239-265. DOI: 10.2478/iclr-2019-0023.

\begin{abstract}
Summary: The EU environmental policy is challenged by current international development (withdrawal of the US from the Paris climate accord, melting of the Arctic, changes in climate, extreme weather events), the sustainable development policy agenda and also by public pressure. The interest of the public in the environmental policy is not only reflected in the Eurobarometer polls, the increase of green parties in $2019 \mathrm{EP}$ elections, but it is also present in the very first European Citizens' Initiative, the environmentally oriented Right2Water initiative, which had been presented to the Commission in 2013. Following the need to reflect upon the current problems and challenges, the scope of European Environmental Policy (EEP) has broadened from traditional direct environmental challenges, such as access to clean water, clean air, maintaining biodiversity also to other areas connected to current challenges as the climate change and sustainable development and into practical implementation in particular internal and external policies - including trade policy, competition policy or public procurement.
\end{abstract}

1 The paper was prepared within project APVV-17-0641 "Improvement of effectiveness of legal regulation of public procurement and its application within EU law context".

2 The paper was prepared within project APVV-17-0641 "Improvement of effectiveness of legal regulation of public procurement and its application within EU law context”.

3 The paper was prepared within project APVV-16-0540 „Human Rights and Sustainable Development in the EU external Relations" 
Following analysis is focused on the position of the green agenda and EEP transfer to legislation in public procurement on European level.

Keywords: Sustainable development - environmental policy - public procurement division of competences

\section{Introduction}

Tackling environmental issues became of high importance on international level. Environmental agenda became part of sustainable development goals (SDG) and requests both legislation and application on national and international level. It is visible from the agenda of President-elect of the European Commission Ursula von der Leyen that environmental issues will be crucial in European politics when she put "A European Green Deal" on the first place of her Political Guidelines ${ }^{4}$ and confirming this devotion during her presentation of her team: "I want the European Green Deal to become Europe's hallmark. At the heart of it is our commitment to becoming the world's first climate-neutral continent. It is also a long-term economic imperative: those who act first and fastest will be the ones who grasp the opportunities from the ecological transition. I want Europe to be the front-runner. I want Europe to be the exporter of knowledge, technologies and best practice." ${ }^{5}$

Since the foundation of European Coal and Steal Community, the agenda of environmental policy has been present in the cooperation between Member States, both internally and externally. It is a certain paradox that in certain aspects are external powers of the Union broader developed and exercised comparing to internal policies. Within the internal policies, the EU is restricted by sovereignty of the Member States that cannot be frustrated even with their consent (due to principle of conferral). Under Art. 21(2)d) TEU the EU shall "foster the sustainable economic, social and environmental development of developing countries, with the primary aim of eradicating poverty". There can be criticism of environmental policy of the EU that allegedly can draw back development of EU industry. On the other hand, there is a legal obligation of the EU to promote protection of environment in relations with the third countries. Such inclusion of environmental standards can lead to spreading EU ecological and eco-friendly requirements worldwide. EU's conditionality on human rights in its external relations is quite well-developed practice ${ }^{6}$ Therefore, it can be considered a good

4 LEYEN, Ursula von der. A Union that strives for more. My agenda for Europe. Political Guidelines for the Next European Commission 2019-2024. 2019. < https://ec.europa.eu/ commission/sites/beta-political/files/political-guidelines-next-commission_en.pdf >.

5 EUROPEAN COMMISSION. Press release IP/19/5542: The von der Leyen Commission: for a Union that strives for more. Brussels, 10 September 2019. < https://europa.eu/rapid/ press-release_IP-19-5542_en.htm>

6 E.g. MEISSNER, Katharina L., McKENZIE, Lachlan. The paradox of human rights conditionality in EU trade policy: when strategic interests drive policy outcomes. Journal of European Public Policy, 2018, Vol. 26(9), pp. 1273-1291. 
example for EU environmental values export, too. Also, GSP+ is a tool how to insert environmental conditionality into trade relations. Moreover, EU-Korea FTA can serve as an example of declared cooperation within GPP (annex 13, art $1(\mathrm{~d}))^{7}$. Even currently, according to TREND Analytics ${ }^{8}$, the EU is definitely a world leader in number of provisions of environmental relevance in its trade agreements (3005 comparing to 1325 of the second - the US - and 927 of the third - Canada).

According to the situation in the area of the environmental policy internally, the EU is granted shared competences as to Article 4 TFEU. EU uses to be supporter of the green agenda, in internal policies as well as in the external relations. However, the effectiveness of the implementation of some of the EU's crucial environmental goals in internal policies, when looked at in detail, proves to be more challenging than would be apparent from the confident language used in the EU official communications, documents and speeches of the EU officials responsible for the implementation of the environmental agenda.

As the official EU communication sources claim, "the EU has some of the world's highest environmental standards." However, as the former European Commissioner for environment Janez Potočnik said: "It could be argued that we now have all the environmental legislation we need - although new challenges keep coming up ... But laws alone are not enough. We need to make more effort to ensure that they are properly applied throughout the EU. Full implementation of our laws is a matter not just for European and national authorities, but also for local authorities, businesses and citizens." ${ }^{10}$ In this manner, we consider as important to analyse, how is the legal framework built in area of European environmental policy, but also in relation to its transfer to particular EU policy and its application.

The context analysis will be elaborated, based on the analysis of the primary and secondary sources of EU legislation. Following we will focus on the comparison of de iure regulation to de facto status of implementation within the case study of public procurement.

The case study of public procurement was chosen due fact, that one of the Lisbon Treaty goals in area of environment, as well as the $7^{\text {th }}$ Environmental Action Programme, requests full integration of environmental requirements and considerations into other policies. Public procurement case study may provide space for formulation of recommendations even in de lege ferenda form in gen-

7 Free trade Agreement between the European Union and its Member States, of the one part, and the Republic of Korea, of the other part (OJ L 127, 14.5.2011, p. 6-1343).

8 < https://klimalog.die-gdi.de/trend/> accessed 5 July 2019.

9 EUROPEAN UNION, 'Environment' (European Union, 2019) <https://europa.eu/european-union/topics/environment_en > accessed 19 June 2019

10 JORDAN, Andrew, ADELLE, Camilla. Environmental Policy in the EU, Actors, Institutions and processes, 3rd edn, Routledge, 2013, p. 18. 
eral, but also to review the sustainable development in environmental protection and confirm also the role of the EU as an environmental actor worldwide.

\section{From Conference on Human Environment to Lisbon Treaty}

One of the fundamental notions related to the environmental policy in general, is its transboundary and trans-sectoral character by nature. In general, many environmental phenomena have a transboundary character by nature and hence the policies that strive to successfully address these challenges need to reflect on the transboundary character of both causes and effects of the environmental problems.

The list of the contemporary environmental challenges is far from being exhausted and there is a trend that the more we learn about the environmental challenges, the greater the need for broader and more comprehensive legislative regulation and action is.

"This characteristic transboundary multinational feature of environmental policy explains why the EU has been trying to establish itself as a key actor of Environmental Policy. It also explains the need for effective harmonisation of environmental standards, following an aim of creating an equal harmonised set of environmental norms within the common market, which is a foundation of the economic purpose of the EU integration." 11

Since the 1972 UN Conference on Human Environment, the environmental agenda has gradually started to find its way into European legislation. Throughout the 1980s broader European competences were established at a European level. During the 1990s and 2000s the EU powers in this field expanded further and became more institutionalized at an EU level and supranational decisionmaking became the rule.

Environmental policies in the EC originally had their own environmental justification, without this being subordinated to internal market objectives. On the basis of European Council commitments in 1972 to establish a Community environmental policy, the first Environmental Action Programme (EAP) was decided upon in November $1973 .{ }^{12}$ This programme already established the argument that economic development, prosperity and the protection of the environment are mutually interdependent. It was argued, that "the protection of the environment belongs to the essential tasks of the Community" ${ }^{13}$ It had underlined the need for a comprehensive assessment of the impacts of other policies, in an effort to avoid damaging activities. This first plan devoted most of its atten-

11 DELREUX, Tom, HAPPAERTZ, Sander. Environmental Policy and Politics in the European Union, 1st edn, Macmillan International Higher Education, 2016, pp. 3-4.

12 The programme of action of the European Communities on the environment [1973] OJ $\mathrm{C} 112 / 1$

13 ibid 
tion to water protection and waste, but it also contained a particular reference to agriculture and spatial planning, including also notification of emissions control's preparation. The second Environmental Action Programme ${ }^{14}$ had covered period of 1977 to 1981 and it mainly follow the first one, elaborated more in detail concrete areas and had presented also another area of nature protection. From implementation point of view, both programmes (1973-1981) advocated quality values for water and air. According to this, a number of framework directives were decided during this period.

The third Environmental Action Programme (1982-1986) ${ }^{15}$ emphasised the potential risks and benefits of environmental policies to the internal market and issue linkage between the internal market and environmental policies became a key driver for programming and activities. It had focused mainly on waste avoidance, efficient resource use and integrated environmental technologies. It had also made reference to the first global strategy for "Sustainable Development" formulated by the IUCN in 1980 .

Year 1987 use to be seen as a crucial point in European environmental policy as it has its own chapter in the Single European Act. Pursuant to former articles $130 \mathrm{r}-\mathrm{t}$ - now Art. 192-93 of the Treaty on the Functioning of the European Union (TFEU) - the Council, deciding unanimously and in consultation with the European Parliament (EP), was empowered with specific competences over environmental policy. Although in practice the unanimity requirement left previous practice more-less without-t significant changes, the symbolic importance of having an explicit legal basis for environmental action was enormous.

This strengthening of environmental policy had been also reflected in the fourth Environmental Action Programme (1987-1992). ${ }^{16}$ The main aim of this programme states also in balancing relation between economy (internal market) and environment (including sustainable development). This programme presented the shift in the environmental policy, while recognising previous principles and areas of protection, but also considering transboundary pollution agenda. The programme used the integrative attitude and environmental protection was not perceived as an additive, but rather as an integrated activity within the whole economic production process. It was the fourth Environmental Action Programme, which had notified "sectoral" approach in the sense of analysing the impact of strategic economic sectors on the environment, including evaluation of incentive-based instruments, such as taxes, subsidies or tradable emission permits.

14 The continuation and implementation of a European Community policy and action programme on the environment [1977] OJ C 139/1

15 The continuation and implementation of a European Community policy and action programme on the environment (1982 to 1986) [1983] OJ C 46/1

16 The continuation and implementation of a European Community policy and action programme on the environment (1987-1992) [1987] OJ C 328/1 
However Maastricht Treaty did not represent any specific innovation on environmental legislation, it did add a specific reference to the precautionary principle among the guiding principles of EU environmental policy. ${ }^{17}$ The connected fifth Environmental Action Programme ${ }^{18}$ was then adopted for period of 1992 to 1999. It used to be considered as one presenting strategic shift, when including environmental preferences of citizens, civil society organisations with environmental agenda and public concern in the text. Due this, it includes as priority sustainable development according to the definition of the Brundtland Report ${ }^{19}$, structural change in favour of public transport, energy efficiency and waste prevention, new instruments mainly market-oriented instruments such as fiscal incentives or voluntary instruments, which strengthen producers and consumers own interests in environmental decision-making, consensus-oriented approach taking into account the crucial role of non-governmental protagonists and local/regional authorities to represent the general interest of the environment.

Environmental agenda became visible mainly after Amsterdam Treaty. It added a reference to sustainable development among the Union's objectives and expressly mentioning the achievement of "a high level of protection and improvement of the quality of the environment" among the tasks of the Community. This new formulation in the Treaty was a definite improvement compared to the less incisive reference to "sustainable and non-inflationary growth respecting the environment" in the Maastricht version. The Treaty of Amsterdam also moved up the principle of environmental integration from the specific Environmental Title to article 6 in the section defining the general principles of EU policy.

European Commission, reflecting evaluation of EAPs proposed several crucial legislations always considering both strategic objectives: environmental protection and economic sustainability. Late nineties and beginning of new millennium are known as the period of strategic directives adoption:

- Ambient Air Quality Directive (96/62),

- The Water Framework Directive (2000/60)

- The IPPC-Directive $(1996 / 61)$

- The NEC-Directive (2001/81)

- The Emission Trading Directive (2003/87)

- Directives on air quality $(1999 / 30 ; 2000 / 69 ; 2002 / 3)$,

- The Directive on emission control for cars $(98 / 69)$

17 WILKINSON, David, Maastricht and the Environment: the Implications for the EC's Environment Policy of the Treaty on European Union, Journal of Environmental Law, Volume 4, Issue 2, 1992, p. 224, https://doi.org/10.1093/jel/4.2.221.

18 A European Community programme of policy and action in relation to the environment and sustainable development [1993] OJ C 138/5

19 World commission on environment and development, 'Report of the World Commission on Environment and Development: Our common future ' (United Nations , 1987) < https://sustainabledevelopment.un.org> accessed 20 June 2019 
- The Directive on lorries (99/96),

- The Directive on fuel standards (in 1998)

- The Directive on the large combustion plants (2001)

- The Incineration directives (2000/76),

- The Directive 1999/31/EC on the landfill of waste

- the revision of the Seveso, the Ecolabel and EMAS-directives (End of Life Vehicles (2000/53) and WEEE (2002/96), Strategic Environmental Impact Assessment (2001/42), Environmental Liability (2004), CO2 Emission Trading (2003/87).

- Directives 2003/4,2003/35 and CEC Directive proposal 2003/624 as to Aarhus Convention implementation.

Each piece of legislation was important from the point of the environmental regulation development. European Commission together with European Parliament, Member States and environmental civil society organisations became aware of necessity to include green agenda in European legislation and policies. While primarily these legal acts focused on protection of environment, later development confirmed interaction of environmental agenda with other aspects of internal market (as consumer protection, competition law, public procurement etc.).

This attitude was confirmed in the sixth Environmental Action Programme (2002-2012 $)^{20}$, when economic insight became even more relevant, while focusing on so-called persistent environmental problems as climate change, the loss of biodiversity or the over-consumption of resources require a broader approach beyond environmental legislation. In this period, the Commission was moving from its position as an initiator of legislation to a manager of policy processes and mediator who look on balance between member states' interests, civil society and business enterprises in this area. One of the key environmental legislation in this period was adoption of 2004/35/EC Environmental Liability Directive ${ }^{21}$ as the result of a long and complex process lasting for more than ten decade. The next liability rules follow, the Directive $2005 / 35 / \mathrm{EC}^{22}$ on ship-source pollution and on the introduction of penalties for infringements and the Directive $2008 / 99^{23}$ on the protection of the environment through criminal law, which provides a common framework for penal and administrative sanctions against violations of specific pieces of EU environmental legislation.

The next and currently efficient Treaty of Lisbon on the Functioning of the European Union has contributed to this endeavour, providing a new legal frame-

20 Laying down the Sixth Community Environment Action Programme [2002] OJ 2 242/1-15

21 On environmental liability with regard to the prevention and remedying of environmental damage, [2004] OJ 2 143/56

22 On ship-source pollution and on the introduction of penalties for infringements [2005] OJ L 255/11

23 On the protection of the environment through criminal law [2008] OJ L 328 
work for the adoption of criminal legislation at EU level and development of the strategic documents connected to environment in more comprehensive and precise way. The innovations of the Lisbon Treaty in the sections devoted to the area of environmental policy include two most significant notions:

1. introduction of a sentence mentioning the fight against Climate Change at the international level, which marks the first time that climate change is mentioned in the text of an EU Treaty

2. co-decision legislative procedure mentioned in the previous Treaties has been renamed as the 'ordinary legislative procedure', although the character of the procedure as such has not changed.

The contemporary European Environmental Policy is based on a number of principles. Six of them are explicitly mentioned in the valid Treaty on Functioning European Union:

1. Precautionary principle (Art. 191 (2) TFEU)

2. Preventive action principle (Art. 191 (2) TFEU)

3. Rectification at the source principle (Art. 191 (2) TFEU)

4. Polluter pays principle (Art. 191 (2) TFEU)

5. Environmental integration principle (Art. 11 TFEU)

6. Sustainable development principle (Arts. 3 TEU and 11 TFEU, Art. 37 of the Charter of Fundamental Rights of the European Union).

The reasoning why these principles have been included into the fundamental Treaties reflects on the importance these notions carry for the functioning of the EU itself. "According to the principle of integration, the obligation to protect the environment must be a component of any EU policy"24. The other principles clearly reflect the Union's focus on favouring taking the preventive actions in cases of even potential environmental hazard or hazard towards human health, rather than letting the environmental degradation evolve and then take the remedy actions. "This is the idea behind the notion of 'sustainable development' as well behind the 'precautionary', 'preventive action' and 'rectification at source' principles. The polluter pays principle has its origins in the first Environmental Action Programme and works on the basis of motivating potential polluters to limit their pollution levels by creating financial incentives for more environmentally friendly behaviour."25

This Union approach to the protection and sustainability of the environment was transferred to the seventh Environmental Action Programme ${ }^{26}$ (2013-2020).

24 Treaty of Amsterdam amending the Treaty on European Union, the Treaties establishing the European Communities and certain related acts [1997] OJ $1340 / 01 / 1$

25 DELREUX, Tom, HAPPAERTZ, Sander. Environmental Policy and Politics in the European Union, 1st edn, Macmillan International Higher Education, 2016, pp. 20-22

26 On a General Union Environment Action Programme to 2020 'Living well, within the limits of our planet' Text with EEA relevance [2013] OJ L 354/171 
In order to give more long-term direction, it sets out a vision beyond that, of where it wants the Union to be by 2050: "In 2050, we live well, within the planet's ecological limits. Our prosperity and healthy environment stem from an innovative, circular economy where nothing is wasted and where natural resources are managed sustainably, and biodiversity is protected, valued and restored in ways that enhance our society's resilience. Our low-carbon growth has long been decoupled from resource use, setting the pace for a safe and sustainable global society." The environmental policy

The ongoing EAP identifies three key objectives:

- to protect, conserve and enhance the Union's natural capital

- to turn the Union into a resource-efficient, green, and competitive lowcarbon economy

- to safeguard the Union's citizens from environment-related pressures and risks to health and wellbeing,

and these had been transformed into goals, which member states and EU institutions should achieve by 2020 :

a) better implementation of the legislation,

b) better information by improving the knowledge base,

c) more and wiser investment for the environment and climate policy

d) full integration of environmental requirements and considerations into other policies.

All of them are also included in the Europe 2020 Strategy $^{27}$, which sets out the ambition to achieve "smart, sustainable and inclusive growth" during the 2010-2020 period and of which provisions had been later incorporated into the Europe 2030 targets, 2050 targets and EU contribution to international sustainable development goals.

According to this, our objective is to analyse, how this particular goal of integration of environmental requirements are implemented in the public procurement legislation, still within the existed legal framework of environmental policy on EU level.

\section{Legal framework of European environmental policy}

Once defining European Environmental Policy (EEP), we follow the structural interpretation of Haigh, who distinguishes three levels into which European Environmental Policy can be divided:

27 European union, 'Europe 2020 A European Strategy for smart, sustainable and inclusive growth' (European Commission, 2010) <http://ec.europa.eu/eu2020/pdf/COMPLET\%20 EN\%20BARROSO\%20\%20\%20007\%20-\%20Europe\%202020\%20-\%20EN\%20version. pdf > accessed 19 June 2019 
- „the Treaties as a source of authority and competence to pursue policies, to legislate and to enter into international agreements;

- the strategies and action programmes that set out policy intentions; and

- the individual measures, mostly legislation, which create a framework and tools for achieving the policy intentions ${ }^{\text {“28 }}$

\subsection{Treaties}

As it is proclaimed in the Preamble of the Treaty on European Union ${ }^{29}$ (TEU) and explicitly established in Art. 3 TEU, Union shall work, amongst other, for the sustainable development of Europe, aiming at high level of protection and improvement of the quality of the environment. In its external relations, Union shall contribute to the sustainable development of the Earth. "The founding principles of European environmental policy as major area of EU activity ${ }^{{ }^{3} 30}$, are rooted in mostly in the Articles 191-193 of the Treaty on the Functioning of the European Union (TFEU), but some of them are placed in other provisions of the Treaty, too. Article 191 of the TFEU clearly defines the main scope of the European environmental policy as follows:

"to contribute to pursuit of the following objectives: - preserving, protecting and improving the quality of the environment, - protecting human health, - prudent and rational utilisation of natural resources, - promoting measures at international level to deal with regional or worldwide environmental problems, and in particular combating climate change."31

Principles defined in this article - prevention principle, precautionary principle, polluter pays principle, high level of protection principle and principle of rectification of environmental damages at source are supplemented by the integration principle (Article 11 TFEU), principle of sustainable development (Article $3 \$ 3$ and Article $21 \S 2 . d$ ) TEU, article 11 TFEU, Article 37 of the Charter) and principle of proportionality.

As the European Court of Justice (ECJ) stated in Lirussi and Bizzaro ${ }^{32}$, by virtue of principles of precaution and preventive action, "it is for the Community and the Member States to prevent, reduce and, in so far as is possible, eliminate from the outset, the sources of pollution or nuisance by adopting measures of a nature such as to eliminate recognised risks."

28 HAIGH, Nigel. EU Environmental Policy: Its Journey to Centre Stage, 1st edn, Routledge 2015, pp. 7-8.

29 Consolidated version of the Treaty on European Union [2012] OJ C 326/1

30 DELREUX, Tom, HAPPAERTZ, Sander. Environmental Policy and Politics in the European Union, 1st edn, Macmillan International Higher Education, 2016, pp. 3

31 Consolidated version of the Treaty on the Functioning of the European Union [2012] OJ 1 $326 / 1$

32 Joined Cases C-175/98 \& C-177/98 Paolo Lirussi and Francesca Bizzaro [1999] ECR 1999 I-06881, points $46-51$ 
Principle of rectification of environmental damages at source stresses, that environmental risks must be handled and fought against preferentially at the place of their origin. Such approach ensures the most effective elimination of danger, or at least its reduction. This principle is to be read in conjunction with the polluter pays principle. The ECJ in various judgements defined who is a "polluter" and confirmed shared financial responsibility in polluting chain under the parallel application of the principle of proportionality.

For example, in Standley ${ }^{33}$, when regarding the responsibility of UK's farmers for water pollution caused by nitrates from agricultural sources, ECJ held, that under Directive concerning the protection of waters against pollution caused by nitrates from agricultural sources (OJ 1991 L 375, p. 1) Member States, when adopting action programmes applicable to vulnerable zones, were to take into account of available scientific and technical data with reference to the respective nitrogen quantities originating from agricultural and other sources and of environmental conditions in the relevant regions. Also, the Member States were required to draw up and implement suitable monitoring programmes to assess the effectiveness of the action programmes and they were to review and, if necessary, revise their action programmes at least every four years. They could thus take account of changes of circumstance in relation to pollution from both agricultural and other sources. As regards the polluter pays principle, the ECJ stated that the Directive does not mean that farmers must take on burdens for the elimination of pollution to which they have not contributed. Member States are to take account of the other sources of pollution when implementing the Directive and, having regard to the circumstances, are not to impose on farmers costs of eliminating pollution that are unnecessary. Viewed in that light, the polluter pays principle reflects the principle of proportionality.

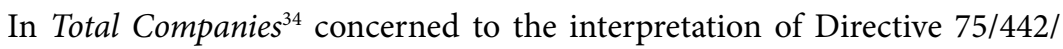
EEC on waste (OJ 1975 L 194, p. 39), the ECJ decided, that hydrocarbons accidentally spilled at sea following a shipwreck, mixed with water and sediment and drifting along the coast of a Member State until being washed up on that coast, constitute waste within the meaning of Directive 75/442, where they are no longer capable of being exploited or marketed without prior processing. On the following question, whether, in the event of the sinking of an oil tanker, the producer of the heavy fuel oil spilled at sea and/or the seller of the fuel and charterer of the ship carrying the fuel may be required to bear the cost of disposing of the waste thus generated, even though the substance spilled at sea was transported by a carrier by sea, ECJ answered that, in accordance with the 'polluter pays' principle, the cost of disposing of the waste is to be borne by the previous holders or the producer of the product from which the waste came. Furthermore, ECJ

33 Case C-293/97 H.A. Standley and Others and D.G.D. Metson and Others, [1999] ECR 1999 I-02603, point 51

34 Case C-188/07 Commune de Mesquer v. Total France, SA, Total International, Ltd. [2008] RC 2008 I-04501 
stated that, the seller of those hydrocarbons and charterer of the ship carrying them might be regarded as a producer of that waste and thereby as a 'previous holder' for the purposes of defining the subject bound to bear costs of disposing of waste, if national court, in the light of the elements which it alone is in a position to assess, reaches the conclusion that that seller-charterer contributed to the risk that the pollution caused by the shipwreck would occur, in particular if he failed to take measures to prevent such an incident, such as measures concerning the choice of ship. Besides, if it happens that the cost of disposing of the waste produced by an accidental spillage of hydrocarbons at sea is not borne by the International Oil Pollution Compensation Fund, or cannot be borne because the ceiling for compensation for that accident has been reached, and that, in accordance with the limitations and/or exemptions of liability laid down, the national law of a Member State, including the law derived from international agreements, prevents that cost from being borne by the shipowner and/or the charterer, even though they are to be regarded as 'holders', such a national law will then, have to make provision for that cost to be borne by the producer of the product from which the waste thus spread came. In accordance with the 'polluter pays' principle, however, such a producer cannot be liable to bear that cost unless he has contributed by his conduct to the risk that the pollution caused by the shipwreck will occur. Proportionality therefore limits the extended application of this principle.

Cross-cutting integration principle requires the integration of environmental protection into the definition and implementation of the EU's policies and activities with a view to promotion sustainable development. Environmental protection must be therefore applied both ways horizontally (as cross-cutting theme) and vertically (as the prime objective). At the same time, it must be noted, that the ECJ confirmed the protection of environment as mandatory requirement ${ }^{35}$ within the concept of case Cassis de Dijon ${ }^{36}$.

According the Art. 191 (3) TFEU in preparing its policy on the environment, the Union shall take account of available scientific and technical data, environmental conditions in the various regions of the Union, the potential benefits and costs of action or lack of action, the economic and social development of the Union as a whole and the balanced development of its regions. As it's clear from above mentioned case Standley, such consideration is required even from the Member States when adopting environmental legislation at national level.

Lisbon Treaty strengthened the international support of environmental policy by the EU and its Member States. In this relation we consider notable, that even if Art. 191 (4) TFEU explicitly stipulates, that cooperation of the EU and

35 Case C-302/86 Commission of the European Communities v Kingdom of Denmark [1988] ECR 198804607

36 Case 120/78 Rewe-Zentral AG v Bundesmonopolverwaltung für Branntwein [1979] ECR 1979-00649 
Member states with international organisations or third countries shall be without prejudice to Member States' competence to negotiate in international bodies and to conclude international agreements, own competences of Member States are in fact limited by the cross-cutting principle of loyalty.

Application of the principle of loyalty $\mathrm{v}$ competences of Member States in external relations was already tested by the ECJ in $E A R T^{37}$ case. In this decision the ECJ stated that "each time the Community, with a view to implementing a common policy envisaged by the Treaty, adopts provisions laying down common rules, whatever form these may take, the Member States no longer have the rights, acting individually or even collectively, to undertake obligations with third countries which affect those rules. If Community rules are promulgated for attainment of the objectives of the Treaty, the Member States cannot, outside the framework of the Community institutions, assume obligations which might affect those rules or alter their scope". This can be interpreted also as prohibition for Member States to exercise their external competences (and interests) when such action is capable to affect the internal rules of the Community or alter their scope.

Later, in its Opinion $2 / 91^{38}$ the ECJ precised that the Community's tasks and the objectives of the Treaty would also be compromised if Member States were able to enter into international commitments containing rules capable of affecting rules already adopted in areas falling outside common policies or of altering their scope.

In 2000, then ECJ extended EART doctrine in its Commission v. Denmark judgement ${ }^{39}$ by decision, that "Member States may not enter into international commitments outside the framework of the Community institutions, even if there is no contradiction between those commitments and the common rules".

In $2006 \mathrm{ECJ}$ emphasized ${ }^{40}$ that it is essential to ensure a uniform and consistent application of the Community rules and the proper functioning of the system which they establish in order to preserve the full effectiveness of Community law.

Finally, in (2009) Commission $v$ Greece ${ }^{41}$ CJEU held that the mere fact that the Community is not a member of an international organisation in no way author-

37 Case 22/70 Commission of the European Communities v Council of the European Communities [1971] ECR 197100263

38 Opinion 2/91 Convention $N^{o} 170$ of the International Labour Organization concerning safety in the use of chemicals at work [1993] ECR 1993 I-01061

39 Case C-467/98 Commission of the European Communities v Kingdom of Denmark [2002] ECR 2002 I-09519

40 Opinion 1/03 Competence of the Community to conclude the new Lugano Convention on jurisdiction and the recognition and enforcement of judgments in civil and commercial matters [2006] ECR 2006 I-01145

41 Case C-45/07 Commission of the European Communities v Hellenic Republic [2009] ECR 2009 I-00701 
ises a Member State, acting individually in the context of its participation in an international organisation, to assume obligations likely to affect Community rules promulgated for the attainment of the objectives of the Treaty. Moreover, the fact that the Community is not a member of an international organisation does not prevent its external competence from being in fact exercised, in particular through the Member States acting jointly in the Union's interest.

That means, that Member State, while exercising its own recognised competences in external relations, has always duty to take into consideration its commitments within the Union and Union's interests. This includes the obligation of Member State to consult and coordinate all its positions with the Union before adopting its position within the organization, where the Member State, nor the Union is a member.

"Internal" EU actions to be taken in order to achieved environmental goals (preserving, protecting and improving the quality of the environment; protecting human health; prudent and rational utilisation of natural resources; promoting measures at international level to deal with regional or worldwide environmental problems, and in particular combating climate change) are covered by Art. 192 TFEU. Such actions are decided by the European Parliament and the Council in accordance with the ordinary legislative procedure and after consulting the Economic and Social Committee and the Committee of the Regions. The same procedure is applicable when adopting the general action programmes setting out priority objectives to be attained.

When adopting provisions primarily of a fiscal nature; or measures affecting:- town and country planning, - quantitative management of water resources or affecting, directly or indirectly, the availability of those resources, - land use, with the exception of waste management; or measures significantly affecting a Member State's choice between different energy sources and the general structure of its energy supply, the Council shall act unanimously in accordance with a special legislative procedure and after consulting the European Parliament, the Economic and Social Committee and the Committee of the Regions. The exemption from this rule may arise, when the Council, acting unanimously on a proposal from the Commission and after consulting the European Parliament, the Economic and Social Committee and the Committee of the Regions, may make applicable the ordinary legislative procedure either on these matters. 


\subsection{Strategies and action programmes}

As stated in first chapter, the essential environmental strategy can be found in Environmental Action programmes. The recent $7^{\text {th }}$ EAP reflects the goals set in United Nations 2030 Agenda for Sustainable development ${ }^{42}$ and related Sustainable Development Goals.

It is implemented by various sectoral programs and strategies, such for example are 2018 Circular Economy Package, 2018 Waste Package, 2013 EU Strategy on Adaptation to Climate Change, 2017 The EU Action plan for nature, people and the economy, 2014 The EU biodiversity strategy, The 2011 Roadmap to a Resource Efficient Europe, 2008 Marine Strategy Framework, 2013 the Clean Air Programme for Europe, etc.

The implementation of existing EU Environmental Policy is from $2017 \mathrm{regu}$ larly reviewed on two-years basis through the Environmental Implementation Review (EIR) provided by the Commission. EIR consists of Commission's communication and country reports. Towards the structure of the reports, they follow the structure of the 7th EAP, and refer to the 2030 Agenda for Sustainable Development and SDGs to the extent to which they reflect the obligations and policy objectives of EU environmental law.

The 2019 EIR $^{43}$ aims at improving implementation in the field of EU environmental policy and legislation by identifying the causes of implementation gaps and addressing systemic obstacles to environmental integration across policy sectors. It also maps the main challenges for each Member State, as well as existing good practices and points of excellence. The main challenges identified take account of factors such as the impact on citizens' quality of life, the progress made to date in meeting the EU environmental targets and the resource implications. It also identifies common challenges and provides preliminary conclusions on possible root causes of poor performance by Member States. On that basis, it proposes structural ways forward to deliver better results in addition to the specific priority actions included in the country reports.

\subsection{Measures}

Environmental area belongs under shared competences of the EU and Member States (Art. 4 (2) TFEU). Therefore, most deliverables have the form of direc-

42 United Nations: „Transforming our world: the 2030 Agenda for Sustainable Development“ [2015] A/RES/70/1

43 European Commission: Communication from the Commission to the European Parliament, the Council, the European Economic and Social Committee and the Committee of the Regions „Environmental Implementation Review 2019: A Europe that protects its citizens and enhances their quality of life" [2019] Com (2019) 149 final 
tives (for example protection of water ${ }^{44}$, air ${ }^{45}$, climate $^{46}$, nature and biodiversity ${ }^{47}$, waste management ${ }^{48}$, noise pollution ${ }^{49}$, circular economy ${ }^{50}$ ).

As it is not the aim of this article to provide exhaustive enumeration of whole environmental legislation and its throughout examination, we would like to point out either to other measures.

Resulting from the above mentioned 2019 EIR, financial incentives and economic instruments offer an effective and efficient way of achieving environmental policy objectives. Amongst the most effective ones, we can find green taxation, environmental funding and green public procurement.

Resuming from the policy findings, the ratio of environmental taxes to GDP varies from around $1.7 \%$ (Luxembourg, Slovakia) to $4 \%$ (Greece). Taxing pollution and resource use encourages consumers to make socially and environmentally beneficial choices. It also generates budget revenues.

Within the European Structural and Investment Funds (ESIF), 'environmental protection and resource efficiency' constitutes the highest allocation in the 2014-20 period in 12 Member States (Austria, Bulgaria, Croatia, Cyprus, Denmark, Finland, France, Greece, Ireland, Luxembourg, Malta and Sweden). ESIF rules oblige Member States to promote environment and climate in their funding strategies and programmes for economic, social and territorial cohesion, rural development and maritime policy. Achieving sustainability goals requires the mobilisation of public and private sources of financing. For its part, the Commission adopted an action plan in March 2018 on financing sustainable

44 E.g. Directive establishing a framework for Community action in the field of water policy [2000] OJ 2 327/1-73; Directive on the quality of water intended for human consumption [1998] OJ 2 330/32-54; Directive establishing a framework for community action in the field of marine environmental policy (Marine Strategy Framework Directive)[2008] OJ 2 164/19-40; Directive establishing a framework for maritime spatial planning [2014] OJ 2 257/135-145

45 E. g. Directive on ambient air quality and cleaner air for Europe [2008] OJ 2 152/1-44

46 E. g. Regulation (EU) on a mechanism for monitoring and reporting greenhouse gas emissions and for reporting other information at national and Union level relevant to climate change and repealing Decision No 280/2004/EC [2013] OJ 2 165/13-40; Regulation (EU) setting $\mathrm{CO} 2$ emission performance standards for new passenger cars and for new light commercial vehicles, and repealing Regulations (EC) No 443/2009 and (EU) No 510/2011 [2019] OJ 2 111/13-53

47 E. g. Directive on the conservation of natural habitats and of wild fauna and flora [1992] OJ 2 206/7-50; Directive on the conservation of wild birds [2010] OJ 2 20/7-25

48 Publications Office of the European Union, Waste Package [2018] OJ L 150 vol. 61

49 E. g. Directive relating to the assessment and management of environmental noise - Declaration by the Commission in the Conciliation Committee on the Directive relating to the assessment and management of environmental noise [2002] OJ 2 189/12-25; Directive on industrial emissions (integrated pollution prevention and control) [2010] OJ 2 334/17-119

50 European Commission, 2018 Circular Economy Package, <http://ec.europa.eu/environment/circular-economy/index_en.htm> accessed 2 July 2019 
growth ${ }^{51}$. Making good use of the ESIF, not only by adequate planning but also when spending, is essential for meeting the environmental goals and integrating them into other policy areas.

The EU green public procurement policies encourage Member States to take further steps to apply green procurement criteria to at least $50 \%$ of public tenders. As the purchasing power of public procurement amounts to around EUR 1.8 trillion in the EU (approximately $14 \%$ of GDP) and a substantial proportion of this money goes to sectors with a high environmental impact, Commission considers public procurement as a strategic tool to support environmental protection. Due to this reason, we dedicated to Green Public Procurement a separate part of this article, where we realise its thorough examination as an example of European policy implementation.

As good practice example of the Green Public Procurement may be used the implementation in several EU Member States, that according to study of PricewaterhouseCoopers conducted in 2009 in Sweden, Finland, Denmark, the Netherlands, United Kingdom, Germany and Austria found, that about 55\% of procurement procedures (accounting for $45 \%$ of total contract value) included green criteria in the years 2006-2007. A study of Essig, Kahlenborn, Moser published in 2011 (analysis of a survey of 2300 contacting authorities within EU and EEA member states) concerned the strategic use of public procurement to achieve horizontal objective. It showed, that $64 \%$ of the respondent contracting authorities included environmental requirements in their tenders "regularly, sometimes or as much as possible.".

\section{Public procurement as example of European environmental policy application}

\subsection{Green procurement - introductory consideration}

As stated above Green Public Procurement (GPP) is beside Green taxation and Environmental Funding considered to be one of the most effective implementation tools for EEP. "Green public procurement encourages public authorities to procure goods and services that have a reduced environmental impact throughout their life cycle when compared to comparable goods and services that would otherwise be procured. The purchasing power of public procurement amounts to approximately $14 \%$ of GDP. A substantial proportion of this money goes to sectors with a high environmental impact such as construction or transport. Therefore, GPP can help to significantly lower the negative impact of pub-

51 Action Plan: Financing Sustainable Growth, [2018] COM/2018/097 final

52 DRAGOS, Dacian; NEAMTU, Bogdana. Sustainable Public Procurement in the EU: Experiences and Prospects. Francois Lichere, Roberto Caranta, Steen Treumer (eds), Novelties in the 2014 Directive on Public Procurement, DJOF Publishing, December 2014. <https:// papers.ssrn.com/sol3/papers.cfm?abstract_id=2488047>accessed 30 September 2019 
lic spending on the environment and can help support sustainable innovative businesses." 53

Green procurement (both public and private) can include several factors, objectives and socio-economic goals:

1. seeking green/environmentally friendly products or services ("core" green procurement), i.e. products and services that minimize their environmental impact during life cycle (e.g. lower CO2 and NOx emissions, decreasing water consumption);

2. focus on social and economic aspects of procurement, i.e. sustainable development;

3. limiting the burden to the environment directly related to policy choices of contacting body;

4. involve and spread a pro-environmental mentality within contracting body, its suppliers as well as general public;

5. support and promote companies that follow eco-friendly criteria as a part of policy. ${ }^{54}$

However, the private and public approach is dramatically different from the point of view of limits of implementation green public procurement. While in the private sector there are no restrictions regarding implementation of green policies, the public bodies shall follow also other statutory duties, seldom directly contradicting to environmental policy.

Thus, public body as a contracting authority can contemplate several policy goals, including effective and eco-friendly performance of its own duties, supporting environmental activities of other public bodies and incentive for environmental and human rights consideration of business actors ${ }^{55}$. As it was noted, implementation of these environmental dimensions in public procurement can be limited internally as well as externally. Internal limits are stemming from the policy attitude of contracting authority itself and follow ideological, partisan and personal mind set of policy maker. External limits are laid down by legislation, local, national and European. European framework of public procurement (PP) is the most visible token of PP rules in Europe. Therefore, it has substantial impact on GPP policy as a whole - positive as well as negative.

53 European Commission, 'Environmental Implementation Review 2019: Policy Background' (EU Environment, 4.4.2019)<http://ec.europa.eu/environment/eir/pdf/eir_2019_ policy_background.pdf $>$ accessed 2 July 2019

54 Cf. ACHILLAS, Charisios, BOCHTIS, Dionysis D., AIDONIS, Dimitrios, FOLLINAS, Dimitris. Green Supply Chain Management, Routledge, 2019, p. 40.

55 For consideration of human rights and environmental standards in public procurement see e.g. our recent paper: BLAŽO, Ondrej, PATAKYOVÁ, M. T., International responsibility of business for violation of human rights - customers perspective. Bialostockie Studia Prawnicze. Vol. 24, Nr. 2 (2019), pp. 101-122 and literature cited therein. 


\subsection{Position of environmental consideration in EU PP framework}

It must be stressed, it the first place, that competence of the EU to establish $\mathrm{PP}$ rules is not explicitly described in the founding treaties. Following provisions are called as a legal basis for PP regulation in the relevant directives: Art. 53(1), Art. 62 and Art. 114 of the TFEU. Thus the EU PP regulation framework seems to be purely free-movement-oriented and focused on harmonization of rules that can create obstacles to internal market. Embedding PP rules the position of "remover of barrier" causes also limits to this legislation itself, because it shall be purely focused on removal of barriers, rather than creating or setting framework for other policies.

Nevertheless, integration of environmental protection and sustainable development (Art. 11 TFEU) is directly invoked in "harmonization article" (Art. 114 TFEU), particularly in par. 3 thereof. It is obvious that some environmental requirements may constitute some restrictions to trade and therefore this protentional conflict must be solved in a treaty-sound manner. The wording of Art. 11 TFEU (“...must be integrated into the definition and implementation ...") says little about position of environmental policy itself vis-à-vis other policies of internal market in case of their potential conflict.

Three possible scenarios may be considered:

1. supremacy of internal market policy (environmental requirements are "integrated" as far as their not undermine or weaken other internal market policy);

2. equality of all policies from the "constitutional" point of view, i.e. there is no supremacy rule in relation between internal market harmonization requirement and environmental requirement (Praktische Konkordanz or other similar approach shall be employed);

3. supremacy of environmental policy, i.e. harmonization rules cannot frustrate any environmental and sustainability requirements.

In order to assess possible hierarchy between respective rules, the CJ EU saw crucial interpretative clause of Art. 11 TFEU in Art 114(3) and the very aim of harmonization, i.e. whether there is an action for harmonization "concerning health, safety, environmental protection and consumer protection". On the one hand the CJEU stressed that Art. 11 TFEU (ex Art. 6 TEC) is "a provision which emphasises the fundamental nature of that objective and its extension across the range of those policies and activities ${ }^{\text {" }}{ }^{56}$ Furthermore, when applying Art. 144(3) TFEU the General Court constantly confirmed that the protection of the environment „...takes precedence over economic considerations, with the result that it may justify adverse economic consequences, even those which are substantial, for

56 Case C-176/03 Commission of the European Communities $v$ Council of the European Union, [2005] ECR 2005 I-07879, par. 42. 
certain traders..." 57 On the other hand the General Court found that "protection of the environment does not constitute, per se, one of the components of that internal market, defined as an area without internal frontiers in which the free movement of goods, persons, services and capital is ensured (Article 26(2) TFEU). ${ }^{58}$ It is evident from this dual approach of the CJEU that relevance and position of environmental standards vary depending on the purpose of EU regulation itself. Despite a legal obligation to integrate protection of environmental issues in all EU policies. (Art. 11 TFEU), merely in pure environmentally focused acts (Art. 114 par.3 TFEU) is the Commission bound to "take as a base a high level of protection". In other areas of harmonization (PP included) the requirement of the level of protection remained ambiguous.

Indeed, position of Art. 37 of the Charter of Fundamental Rights of the EU does not help to solve "integration" duty: "A high level of environmental protection and the improvement of the quality of the environment must be integrated into the policies of the Union and ensured in accordance with the principle of sustainable development." Kingston notes that this provision may insert "high level of environmental protection and the improvement of the quality of the environment" into values of the EU (Art. 2 TEU) via broad human rights concept. ${ }^{59}$ Level of protection enshrined in Art. 37 of the Charter goes definitely beyond pure "integration" under Art. 11 TFEU. Nevertheless, Art. 51(2) of the Charter seems to be crucial in this context together with the principles of conferral, proportionality and subsidiarity. Hence even values of the European union must be pursued by "constitutional" manner and enforcement of the values of the Union (common to the Union and the Member States) by the Union itself is limited to powers of the EU and conferral of powers to the EU.

This ideological dichotomy is apparent from the PP Directive ${ }^{60}$. While recalling Art. 11 TFEU it focuses on clarification "how the contracting authorities can contribute to the protection of the environment and the promotion of sustainable development, whilst ensuring that they can obtain the best value for money for their contracts." (Rec. 91). Integration of environmental policies (as well as social and labour standards) shall be performed by measures "applied in conformity with the basic principles of Union law in particular with a view to ensuring equal treatment...", i.e in a way that „does not discriminate directly or indirectly against

57 Eg. Case T-429/13 Bayer CropScience AG and Others v European Commission, ECLI:EU:T:2018:280, par. 106 and case-law cited therein.

58 Case T-57/11 Castelnou Energía, SL v European Commission, ECLI:EU:T:2014:1021, par. 189.

59 KINGSTON, Suzanne, The uneasy relationship between EU environmental and economic policies. In: SJÅFJELL, Beate, WIESBROCK, Anja (eds.), Sustainable public procurement under EU law, Cambridge University Press, 2016, p. 24.

60 Directive 2014/24/EU of the European Parliament and of the Council of 26 February 2014 on public procurement and repealing Directive 2004/18/EC (OJ L 94, 28.3.2014, p. 65-242). For the purposes of this paper directive 2014/24/EU will be analysed only. Other directives dealing with PP (utilities, sector and defence directives) do not contain other approach. 
economic operators and workers from other Member States." (Rec. 37). Similarly, requirement that eco-labels and other labels shall be "linked to the subject-matter of the contract, such as the description of the product and its presentation, including packaging requirements" is carved into Rec. 75 . Thus, the PP Directive is definitely not a measure under Art. 114(3) TFEU requiring high standards of environmental protection but a measure integrating, in a certain way, environmental consideration into internal market unification.

\section{cted? \\ 4.3 Different approaches to GPP in the PP Directive - connected or disconne-}

The PP Directive provide several levels of integration of environmental consideration into PP - from mandatory consideration to prohibited restrictions, even if they are connected with environmental requirements and policies.

First, according to Article 18(2) "Member States shall take appropriate measures to ensure that in the performance of public contracts economic operators comply with applicable obligations in the fields of environmental, social and labour law established by Union law, national law, collective agreements or by the international environmental, social and labour law provisions listed in Annex $X^{\text {“. }}$

Second, under Article 56(1) „Contracting authorities may decide not to award a contract to the tenderer submitting the most economically advantageous tender where they have established that the tender does not comply with the applicable obligations referred to in Article 18(2)."

Third, under Article 57(4)(a) „Contracting authorities may exclude or may be required by Member States to exclude from participation in a procurement procedure any economic operator (...) where the contracting authority can demonstrate by any appropriate means a violation of applicable obligations referred to in Article 18(2)...".

Fourth, contracting authority shall require explanation of abnormally low tenders, particularly in relation to, inter alia, compliance with obligation referred to in Article 18(2).

Difference between these provisions is apparent: Article 18(2) constitutes mandatory duty of the Member State, however it does not provide certain form of transposition of this duty, and Articles 56(1), 57(4)(a) and 69 (2)(d) are enabling contracting authority to enforce requirements laid down by Article 18(2), however this provision of the directive is optional or merely "enabling".

These provisions themselves create several levels of "green" approach to economic operator.

First level, and the only mandatory level, prohibits violation of environmental rules in performance of the awards contract itself. In fact, such requirements cannot be labelled as GPP rules and it is truly minimal-standard integration of 
Art. 11 TFEU into PP, i.e. performance of public contract itself cannot violate environmental rules.

The second level, explicit and optional, allows exclude economic operators that have violated environmental rules in past.

Both of these levels say very little about GPP dimension and approach since they are outlawing gross "non-environmental" behaviour but does not promote protection of environment or foster its development, including eco-friendly technologies or corporate structures.

The third level of approach to economic operators is hypothetical since it is not described in the PP Directive. Such level may include favouring economic operators with eco-friendly performance of their activities and eco-friendly supply chains. In this context, Rec. 97 of the PP Directive seems to be strict: "However, the condition of a link with the subject-matter of the contract excludes criteria and conditions relating to general corporate policy, which cannot be considered as a factor characterising the specific process of production or provision of the purchased works, supplies or services. Contracting authorities should hence not be allowed to require tenderers to have a certain corporate social or environmental responsibility policy in place." Although the preamble does not have normative power, this non-ambiguous wording is a strong interpretative measure. Furthermore, this approach was developed also in Max Havelaar case where AG Kokott used similar wording: "As to the substance, I agree with the Commission that Article 26 of Directive 2004/18 does not permit the contracting authority to exercise unlimited influence over the purchasing policy of its future contractor. Its requirements in respect of that purchasing policy must relate specifically to the subjectmatter-of the public supply contract (30) and may not concern, for example, the contractor's purchasing policy in general. The contracting authority cannot therefore require that potential tenders have only fair trade products in their product range, but merely that the products to be supplied to it specifically under a public contract be fair trade." ${ }^{\prime \prime 1}$ Thus contracting authority cannot require economic operator to be eco-friendly as a generally principle, but merely eco-friendly when performing contract.

The link to the subject-matter is the focal point for GPP. Environmental requirements and standards may be required as far as they are linked to the subject-matter of the contract:

- $\quad$ in relation to technical specification (Art. 21(1) PP Directive)

- $\quad$ in relation to the criteria underlying labels (Art. 43(1)(a) PP Directive)

- $\quad$ in relation to variants (Art. 45(1) PP Directive)

- $\quad$ in relation to selection criteria (Art. 58(1) PP Directive)

- $\quad$ in relation to award criteria (Art. 67(2) PP Directive)

61 Opinion of AG Kokott, Case C-368/10 European Commission v Kingdom of the Netherlands, ECLI:EU:C:2011:840, par. 88. 
- $\quad$ in relation to contract performance (Art. 70 PP Directive $)^{62}$

Concordia case is the first case in which the CJEU confirmed that environmental criteria can be included in award criteria: “... where ... contracting authority decides to award a contract to the tenderer who submits the economically most advantageous tender, it may take into consideration ecological criteria such as the level of nitrogen oxide emissions or the noise level of the buses, provided that they are linked to the subject-matter of the contract, do not confer an unrestricted freedom of choice on the authority, are expressly mentioned in the contract documents or the tender notice, and comply with all the fundamental principles of Community law, in particular the principle of non-discrimination." ${ }^{\text {63 }}$

To sum up, the PP Directive can be hardly considered GPP measure although it "enables" and "allows" GPP under still strict rules. The PP Directive truly enables contracting authorities to employ principles of GPP, particularly via technical standards or assessment of life cycle costs where environmental externalities can be included into the calculation. However, GPP still remains "optional" or voluntary" and depends on the decision of contracting authority or general policy of a Member State.

Nevertheless, the EU developed other rules of "mandatory" GPP. Zeroenergy plan can serve as an example of mandatory GPP. Under Art. 9(1)(b) of the Energy Performance of Buildings Directive "Member States shall ensure that after 31 December 2018, new buildings occupied and owned by public authorities are nearly zero-energy buildings ${ }^{\text {"64. }}$. Similarly, the Clean Vehicles Directive $^{65}$ required minimal list of the operational lifetime energy and environmental impacts that shall be considered when purchasing road transport vehicles. However, this approach regarding vehicles was abandoned due to the substantial amendment of the Clean Vehicles Directive and "performance" assessment was replaced by "targeting" of amount of "clean vehicles". ${ }^{66}$ Minimal standards for energetical effectiveness of office equipment are enshrined into regulation implementing the Agreement of 20 December 2006 between the Government of the United States of America and the European Community on the coordination

62 For further details see Abby Semple, The link to the subject matter. A glass ceiling for sustainable public contarcts? In: Beate Sjåfjell and Anja Wiesbrock (eds.), Sustainable public procurement under EU law (Cambridge University Press, 2016), p. 50-74.

63 Case-513/99 Concordia Bus Finland Oy Ab, formerly Stagecoach Finland Oy Abv Helsingin kaupunki and HKL-Bussiliikenne [2002] 2002 I-07213.

64 Directive 2010/31/EU of the European Parliament and of the Council of 19 May 2010 on the energy performance of building (OJ L 153, 18.6.2010, p. 13-35).

65 Directive 2009/33/EC of the European Parliament and of the Council of 23 April 2009 on the promotion of clean and energy-efficient road transport vehicles (OJ L 120, 15.5.2009, p. 5-12).

66 Directive (EU) 2019/1161 of the European Parliament and of the Council of 20 June 2019 amending Directive 2009/33/EC on the promotion of clean and energy-efficient road transport vehicles (OJ L 188, 12.7.2019, p. 116-130). 
of energy-efficiency labelling programmes for office equipment ${ }^{67}$. The "Energy Star" regulation requires contracting authorities to specify energy-efficiency requirements not less demanding than "Common Specifications", i.e. standards for Energy star ecolabel. ${ }^{68}$

The GPP is one of the environmental initiatives of the European Commis$\operatorname{sion}^{69}$. This initiative is, from the legal point of view, a set of recommendation and best practices rather than regulatory framework. It focuses on the set of GPP criteria that, in the opinion of the European Commission, fulfil both eco-friendly character and limits of EU PP rules. Since these criteria are not mandatory, Commissioner Potočnik's quote referred in the beginning of this paper must be recalled - it is a mission and a duty of central and local authority to include GPP as an integral part of their performance policies. Hence soft law of the European Commission and true devotion of contracting authorities to environmental policy can create a real connection between PP and environmental policy and join them into coherent and effective tool.

\section{Conclusion}

"In its most basic form, right to environment could be associated with the existence of an environment that is suitable for sustaining a human life that is a "viable" environment in a literal sense. Human right to environment can also be defined as the right of the person to live in the environment, which allows him to satisfy his or her basic living needs and to use it in his favour, so as not to reduce the diversity of nature and preserve the natural functions of ecosystems. The right of an individual to environment has the character of a subjective public right, which enables to meet to human being basic living needs".70

The European Union considers itself as a world leader in environmental protection and environmental standards in order to provide more than "viable" environment but also provide incentives for its development. This political goal is obviously in tension with economic aspects, what is evident also from the wording of the founding treaties and respective case-law. Despite legal obligation to integrate environmental protection into other policies (Art. 11 TFEU) and right for protection of environment (Art. 37 of the Charter), the practical integration into such policies is a complex phenomenon. GPP is one of these "meeting points" of internal market policies and environmental policies. Although PP

67 OJ L 381, 28.12.2006, p. 24-104.

68 Article 7, Regulation (EC) No 106/2008 of the European Parliament and of the Council of 15 January 2008 on a Community energy-efficiency labelling programme for office equipment (recast version) (OJ L 39, 13.2.2008, p. 1-7).

69 For detail, see http://ec.europa.eu/environment/gpp/index_en.htm (accessed 05.07.2019).

70 JANKUV, Juraj. Concept of Substantive Human Right to Environment under International Public Law. International Journal of Liberal Arts and Social Science, 2019, vol. 7(2), pp. 19-29. <https://ijlass.org/articles/7.2.3.19-29.pdf > accessed 21 June 2019 
Directive cannot be clearly considered environmental tool, it can be complemented by several approaches: from bottom, e.g. by involvement and devotion of national and local authorities to implementation of green policies assisted and aided by the European Commission, and from the top, e.g. by introduction of environmental harmonisation, similar to Clean Vehicles Directive or Energy Performance of Buildings Directive. Due to principle of subsidiarity, the first approach is definitely desirable confirming primary responsibility of the Member States for well-being of their citizens. Public procurement is therefore rather connected than disconnected to European Environmental Policy, but surely, this connection needs to be more developed and efficiently applied in the future.

\section{References}

<http://ec.europa.eu/eu2020/pdf/COMPLET\%20EN\%20BARROSO\%20\%20\%20 007\%20-\%20Europe\%202020\%20-\%20EN\%20version.pdf > accessed 19 June 2019

A European Community programme of policy and action in relation to the environment and sustainable development [1993] OJ C 138/5

ACHILlAS, Charisios, BOCHTIS, Dionysis D., AIDONIS, Dimitrios, FOLLINAS, Dimitris. Green Supply Chain Management, Routledge, 2019.

Action Plan: Financing Sustainable Growth, [2018] COM/2018/097 final

BLAŽO, Ondrej, PATAKYOVÁ, M. T., International responsibility of business for violation of human rights - customers perspective. Bialostockie Studia Prawnicze. Vol. 24, Nr. 2 (2019), pp. 101-122.

Consolidated versions of the Treaty on European Union and the Treaty on the Functioning of the European Union [2012] OJ C 326/1

DELREUX, Tom, HAPPAERTZ, Sander. Environmental Policy and Politics in the European Union, 1st edn, Macmillan International Higher Education, 2016, 320 pp.

Directive (EU) 2019/1161 of the European Parliament and of the Council of 20 June 2019 amending Directive 2009/33/EC on the promotion of clean and energy-efficient road transport vehicles (OJ L 188, 12.7.2019, p. 116-130).

Directive 2009/33/EC of the European Parliament and of the Council of 23 April 2009 on the promotion of clean and energy-efficient road transport vehicles (OJ L 120, 15.5.2009, p. 5-12).

Directive 2010/31/EU of the European Parliament and of the Council of 19 May 2010 on the energy performance of building (OJ L 153, 18.6.2010, p. 13-35).

Directive 2014/24/EU of the European Parliament and of the Council of 26 February 2014 on public procurement and repealing Directive 2004/18/EC (OJ L 94, 28.3.2014, p. 65-242).

DRAGOS, Dacian; NEAMTU, Bogdana. Sustainable Public Procurement in the EU: Experiences and Prospects. Francois Lichere, Roberto Caranta, Steen Treumer (eds), Novelties in the 2014 Directive on Public Procurement, DJOF Publishing, December 2014. $<$ https://papers.ssrn.com/sol3/papers.cfm?abstract_id=2488047>accessed 30 September 2019

Environmental Implementation Review 2019: A Europe that protects its citizens and enhances their quality of life" [2019] Com (2019) 149 final 
EUROPEAN COMMISSION. Press release IP/19/5542: The von der Leyen Commission: for a Union that strives for more. Brussels, 10 September 2019. <https://europa.eu/ rapid/press-release_IP-19-5542_en.htm>

EUROPEAN UNION, 'Environment' (European Union, 2019) <https://europa.eu/european-union/topics/environment_en > accessed 19 June 2019

European union, 'Europe 2020 A European Strategy for smart, sustainable and inclusive growth' (European Commission, 2010)

Free trade Agreement between the European Union and its Member States, of the one part, and the Republic of Korea, of the other part (OJ L 127, 14.5.2011, p. 6-1343).

HAIGH, Nigel. EU Environmental Policy: Its Journey to Centre Stage, 1st edn, Routledge 2015.

JANKUV, Juraj. Concept of Substantive Human Right to Environment under International Public Law International Journal of Liberal Arts and Social Science, 2019, vol. 7(2), pp. 19-29. <https://ijlass.org/articles/7.2.3.19-29.pdf > accessed 21 June 2019

JORDAN, Andrew, ADELLE, Camilla. Environmental Policy in the EU, Actors, Institutions and processes, 3rd edn, Routledge, 2013.

Judgment of 20 February 1979, 120/78 Rewe-Zentral AG v Bundesmonopolverwaltung für Branntwein, EU:C:1979:42.

Judgment of 12 February 2009, C-45/07 Commission of the European Communities v Hellenic Republic, EU:C:2009:81.

Judgment of 13 September 2005, C-176/03 Commission of the European Communities $v$ Council of the European Union, EU:C:2005:542.

Judgment of 17 May 2018, T-429/13 Bayer CropScience AG and Others v European Commission, 2018, ECLI:EU:T:2018:280.

Judgment of 17 September 2002, C-513/99 Concordia Bus Finland Oy Ab, formerly Stagecoach Finland $\mathrm{O} y \mathrm{Ab} v$ Helsingin kaupunki and HKL-Bussiliikenne. EU:C:2002:495.

Judgment of 20 September 1988, C-302/86 Commission of the European Communities $v$ Kingdom of Denmark, EU:C:1988:421.

Judgment of 24 June 2008, C-188/07 Commune de Mesquer v. Total France, SA, Total International, Ltd., EU:C:2008:359

Judgment of 29 April 1999, C-293/97 - The Queen v Minister of Agriculture, Fisheries and Food, ex parte Standley and Others, ex parte H.A. Standley and Others and D.G.D. Metson and Others, EU:C:1999:215.

Judgment of 3 December 2014, T-57/11 Castelnou Energía, SL v European Commission, ECLI:EU:T:2014:1021.

Judgment of 31 March 1971, 22/70 Commission of the European Communities v Council of the European Communities, EU:C:1971:32.

Judgment of 5 November 2002, C-467/98 Commission of the European Communities $v$ Kingdom of Denmark, EU:C:2002:625.

Judgment of 5 October 1999, joined Cases C-175/98 \& C-177/98 Paolo Lirussi and Francesca Bizzaro, EU:C:1999:486.

KINGSTON, Suzanne, The uneasy relationship between EU environmental and economic policies. In: SJÅFJELL, Beate, WIESBROCK, Anja (eds.), Sustainable public procurement under EU law, Cambridge University Press, 2016.

Laying down the Sixth Community Environment Action Programme [2002] OJ 2 242/115

LEYEN, Ursula von der. A Union that strives for more. My agenda for Europe. Political Guidelines for the Next European Commission 2019-2024. 2019. < https://ec.europa. 
$\mathrm{eu} /$ commission/sites/beta-political/files/political-guidelines-next-commission en.pdf $>$.

MEISSNER, Katharina L., McKENZIE, Lachlan. The paradox of human rights conditionality in EU trade policy: when strategic interests drive policy outcomes, Journal of European Public Policy, 2018, Vol. 26(9), pp. 1273-1291. <https://doi.org/10.1080/13 501763.2018.1526203> accessed 5 July 2019.

On a General Union Environment Action Programme to 2020 'Living well, within the limits of our planet' Text with EEA relevance [2013] OJ L 354/171

On environmental liability with regard to the prevention and remedying of environmental damage, [2004] OJ 2 143/56

On ship-source pollution and on the introduction of penalties for infringements [2005] OJ L 255/11

On the protection of the environment through criminal law [2008] OJ L 328

Opinion of 19 March 1993, 2/91 Convention $N^{\circ} 170$ of the International Labour Organization concerning safety in the use of chemicals at work, EU:C:1993:106.

Opinion of 7 February 2006, 1/03 Competence of the Community to conclude the new Lugano Convention on jurisdiction and the recognition and enforcement of judgments in civil and commercial matters, EU:C:2006:81.

Opinion of AG Kokott, Case C-368/10 European Commission v Kingdom of the Netherlands, ECLI:EU:C:2011:840.

Regulation (EC) No 106/2008 of the European Parliament and of the Council of 15 January 2008 on a Community energy-efficiency labelling programme for office equipment (recast version) (OJ L 39, 13.2.2008, p. 1-7).

SEMPLE, Abby. The link to the subject matter. A glass ceiling for sustainable public contracts? In: SJÅFJELL, Beate, WIESBROCK, Anja (eds.), Sustainable public procurement under EU law, Cambridge University Press, 2016.

The continuation and implementation of a European Community policy and action programme on the environment [1977] OJ C 139/1

The continuation and implementation of a European Community policy and action programme on the environment (1982 to 1986) [1983] OJ C 46/1

The continuation and implementation of a European Community policy and action programme on the environment (1987-1992) [1987] OJ C 328/1

The programme of action of the European Communities on the environment [1973] OJ $\mathrm{C} 112 / 1$

Treaty of Amsterdam amending the Treaty on European Union, the Treaties establishing the European Communities and certain related acts [1997] OJ $1340 / 01 / 1$

United Nations: „Transforming our world: the 2030 Agenda for Sustainable Development" [2015] A/RES/70/1

WILKINSON, David, Maastricht and the Environment: the Implications for the EC's Environment Policy of the Treaty on European Union, Journal of Environmental Law, Volume 4, Issue 2, 1992, pp. 221-239, https://doi.org/10.1093/jel/4.2.221

World commission on environment and development, 'Report of the World Commission on Environment and Development: Our common future' (United Nations, 1987) $<$ https://sustainabledevelopment.un.org> accessed 20 June 2019 